\title{
COMPARATIVE STUDY ON ACTIVITIES OF ANTI BACILLARY DYSENTRY SHIGELLA DYSENTERIAE OF SYZYGIUM POLYANTHUM AND DRACAENA ANGUSTIFOLIA LEAVES ETHANOL EXTRACTS
}

\author{
SRI AGUNG FITRI K ${ }^{1}$, DANNI RAMDHANI ${ }^{2}$, RESMI MUSTARICHIE ${ }^{2 *}$ \\ ${ }^{1}$ Department of Biological Pharmacy, Faculty of Pharmacy, Universitas Padjadjaran, Indonesia. ${ }^{2}$ Department of Pharmaceutical Analysis \\ and Medicinal Chemistry, Faculty of Pharmacy, Universitas Padjadjaran, Indonesia. \\ Email: rmustarichie@yahoo.com \\ Received: 17 October 2016, Revised and Accepted: 27 October 2016
}

ABSTRACT

Objective: This study aims to determine the antibacterial activity of ethanol extract of bay (Syzygium polyanthum W.) and suji (Dracaena angustifolia Roxb.) leaves against Shigella dysenteriae and the amount of potassium to the discovery of anti-dysentery drug candidates.

Methods: Testing activities and comparative value activities performed by the agar diffusion method, whereas the determination of minimum bactericidal concentration (MBC) was done with the subculture media incubation test followed with microdilution method on Mueller Hinton Agar medium sterile. Potassium levels of the extract were carried out quantitatively using atomic absorption spectrophotometry.

Results: The test results showed that the ethanol extract of both leaves had antibacterial activity against $S$. dysenteriae with MBC values were in the range of $10-20 \% \mathrm{w} / \mathrm{v}$. Value comparative effectiveness suji leaf ethanol extract to the bay leaf was 1:0.4. Potassium levels ethanol extract of bay and suji leaves were $1.027 \%$ and $3.795 \%$, respectively.

Conclusion: It can be concluded that the ethanol extract of bay and suji leaves has antibacterial activity against bacteria S. dysenteriae ATCC 13313 . Rated comparative activity of the ethanol extract of the suji leaves with bay leaves ethanol extract was 1:0.4 which means to generating resistor diameter equal to 1 part suji leaf ethanol extract equivalent to 0.4 parts of the ethanol extract of bay leaves. The minimum kill concentration ethanol extract of bay and suji leaves ethanol extract was in the range of $10-20 \% \mathrm{w} / \mathrm{v}$. Both bay and suji leaves have potential as a supplier of potassium in patients with hypokalemia dysentery.

Keywords: Bay leaves, Suji leaves, Shigella dysenteriae, Potassium, Atomic absorption spectrophotometry.

(C) 2017 The Authors. Published by Innovare Academic Sciences Pvt Ltd. This is an open access article under the CC BY license (http://creativecommons. org/licenses/by/4. 0/) DOI: http://dx.doi.org/10.22159/ajpcr.2017.v10i2.15725

\section{INTRODUCTION}

Dysentery by cause divided into two, namely, amoebic dysentery and bacillary dysentery [1]. Both dysentery generally has the same symptoms, but bacillary dysentery is usually more common in children. Bacillary dysentery is an intestinal infection caused by Gram-negative bacilli of the Shigella dysenteriae [2]. About 1.1 million people are estimated to die each year, with $60 \%$ of the cases are from children under 5 years old [3]. Complications that often arise in bacillary dysentery are dehydrated [4]. Cases of dehydration cause the body to lose a lot of water with salts, especially potassium and sodium [2]. Hypokalemia reported cases are more prevalent. Hypokalemia occurs when the concentration of potassium in the blood of $<3.5 \mathrm{mEq} / \mathrm{L}$ of blood and the risk of death [5]. This danger becomes great for babies and children because it can to lose more body fluid (15\%) compared with adults (4\%). Thus, in addition to a drug given anti-dysentery, required supply potassium to prevent hypokalemia due to dehydration.

Treatment of bacillary dysentery is generally performed by administering tetracycline, ampicillin, cotrimoxazole, ciprofloxacin, and chloramphenicol [6]. However, reported cases of $S$. dysenteriae resistance against the antibiotic is ampicillin (82\%), cotrimoxazole (84\%), and chloramphenicol (82\%) [7]. Thus, the necessary searches anti bacillary dysentery potential candidates to overcome the resistance of existing cases. The use of natural materials is one of the solutions in the discovery of new drugs for anti-bacillary dysentery. Reported that the bay leaves (Syzygium polyanthum W.) and suji leaves (Dracaena angustifolia Roxb.) had a strong bacillary antidisentri activity. In addition, it was reported also that the test material has fairly high potassium content $[8,9]$. This open up a new interest to examine the anti-bacillary dysentery activity comparisons between two as well as their potassium content. Thus, the results of this study were obtained candidate anti bacillary dysentery capable of supplying potassium so as to reduce the death rate of bacillary dysentery patients due to hypokalemia.

\section{METHODS}

Plant material

Plant material samples used in this study was a bay (S. polyanthum W.), and suji leaves (D. angustifolia Roxb.) obtained from Plantation Manoko, Lembang, West Java and determination plants was performed in Taxonomy Laboratory, Department of Biology, Faculty of Mathematics and Natural Sciences, University of Padjadjaran.

\section{Bacteria test}

Bacteria test used is $S$. dysenteriae ATCC 13313.

Media growth of test bacteria was Shigella-Salmonella (SS) (Pronadisa), Mueller-Hinton agar (MHA) (Merck) and Mueller-Hinton broth (MHB) (Oxoid).

\section{Extracttion and extract parameters}

The making extract was done by maceration method. The test material was extracted with ethanol 70\% $3 \times 24 \mathrm{hrs}$. Liquid extract was collected and then concentrated by rotary evaporator at a temperature of $60^{\circ} \mathrm{C}$ to 
obtain a thick extract. Viscous extract and then heated over a water bath at a temperature of $50^{\circ} \mathrm{C}$ to remove residual solvent remaining [10]. Inspection parameters included an examination of the organoleptic, yield, and moisture content of the extract.

\section{Phytochemical screening}

Phytochemical screening was conducted using modified phytochemical screening of plants [11].

\section{Thin layer chromatography (TLC)}

Determination profile TLC was performed using thin layer plate. The stationary phase used was silica gel 60 F254 and the mobile phase was a mixture of chloroform: methanol: 9:1.

\section{Confirmation of test bacteria}

$-24 \mathrm{hrs}$ at a temperature of $37^{\circ} \mathrm{C}$. Colony morphology observed for its shape:

\section{Observation morphology colonies}

Observations colony morphology was done by scraping the bacterial suspension in a sterilized MHB liquid medium on the SS surface. Media were then incubated for 18 and color.

2. Gram-staining

Gram staining was performed by making a smear test bacteria suspension on the slide, and then the slide was passed on fire. Furthermore, a smear on the glass objects imbued with carbolic gentian violet for 1 minute. Excess dye was removed and rinsed with distilled water. Spreadable flooded with Lugol for 2 minutes. Lugol excess then removed and rinsed with distilled water. After this, the smear was washed with $95 \%$ alcohol drop by drop until the dye dissolved and then rinsed with distilled water. Last coloring stage was flooded smear methylene blue for 30 seconds and discharged excess dye and distilled water rinse. Further object glass filter paper and dried with oil immersion plus then observed under a microscope. Gram-positive bacteria in purple and Gram-negative bacteria were blue.

3. Biochemistry test

Biochemistry test was conducted on the motility test, carbohydrate fermentation, Indol, TSIA (Triple Sugar Iron), Urease, methyl red, Voges Prokauer, and citrate.

\section{Antibacterial activities test}

1. Preparation equipment and materials

Before testing the antibacterial activity, tools and materials used for the activity test sterilized using an autoclave at a temperature of $121^{\circ} \mathrm{C}$ for 15 minutes

2. Preparation of bacterial growth media

Solid medium used was that SS and MHA. $63 \mathrm{~g}$ that SS was dissolved in $1 \mathrm{~L}$ of distilled water. Media should not be sterilized by autoclaving. To reduce contamination, and the distilled water used must be sterile. Media in the mix with distilled water in a sterile Erlenmeyer flask aseptically and heated in a water bath until boiling. While the MHA media creation done by dissolving $38 \mathrm{~g}$ of media into $1 \mathrm{~L}$ of distilled water and then heated in a water bath until dissolved. Sterilization media performed by autoclaving at $121^{\circ} \mathrm{C}$ for 15 minutes. $21 \mathrm{~g}$ MHB dissolved in $1 \mathrm{~L}$ of distilled water and heated in a water bath until dissolved. Sterilization media is done with an autoclave at a temperature of $121^{\circ} \mathrm{C}$ for 15 minutes.

3. Preparation of bacteria test

Bacteria embedded test in order SS $5 \mathrm{~mL}$ in a test tube (for oblique) by way of scraping a test bacteria in a zig-zag, then incubated for 18-24 hrs at a temperature of $37^{\circ} \mathrm{C}$

4. Preparation of standard solution McFarland

McFarland standard solution consists of two components, namely, $\mathrm{BaCl}_{2}$ solution of $1 \%$ and $1 \% \mathrm{H}_{2} \mathrm{SO}_{4}$. A total of $0.05 \mathrm{~mL}$ of $1 \% \mathrm{BaCl}_{2}$ solution was mixed with $9.95 \mathrm{~mL}$ of $1 \% \mathrm{H}_{2} \mathrm{SO}_{4}$ solution and shaken until homogeneous. The turbidity of the solution was measured at a wavelength of $620 \mathrm{~nm}$ using distilled water as blank. The absorbance value of the standard solution should be in the range of 0.08 up to $0: 13$. Standard solution equivalent to a $0.5 \mathrm{McF}$ arland suspension of bacterial cells at a concentration of $1.5 \times 108 \mathrm{CFU} / \mathrm{mL}$.
5. Preparation of bacteria suspension

Dysentriae Shigella bacteria which have been cultured in the media so that the SS for $18-24$ hrs at a temperature of $37^{\circ} \mathrm{C}$, taken one Ose, then suspended in sterile MHB. Turbidity bacteria were measured using a standard 0.5 McFarland. Then, incubated at a temperature of $37^{\circ} \mathrm{C}$ for $18-24 \mathrm{hrs}$.

6. Testing antibacterial activity

The method used to test the antibacterial activity of ethanol extract of bay and suji leaves was the agar diffusion method with perforation technique. Bay leaf ethanol extract dissolved in dimethyl sulfoxide (DMSO) to obtain the extract solution with a concentration of $80 \%$, $40 \%, 20 \%$, and $10 \% \mathrm{w} / \mathrm{v}$. Suji leaf ethanol extract dissolved in DMSO to obtain the extract solution with a concentration of $100 \%, 80 \%$, $40 \%, 20 \% \mathrm{w} / \mathrm{v}$. Sterile petri dish diameter of $10 \mathrm{~cm}$ was prepared and into it entered $20 \mathrm{~mL}$ test bacteria suspensions equivalent to McFarland 0.5, then poured agar medium MHA with a temperature of $20 \mathrm{~mL} \pm 400 \mathrm{C}$. Having shaken gently until a homogeneous, test medium was left to solidify. The medium test was divided into four zones and perforated using a perforator. A volume of $100 \mathrm{~mL}$ of the extract solution with different concentrations inserted into a hole on each cup. Grail incubated in an incubator at $37^{\circ} \mathrm{C}$ for $18-24 \mathrm{hrs}$. Tests conducted triplo for each cup. As a positive control, sterile petri dish diameter of $5 \mathrm{~cm}$ was prepared and poured into it order MHA $40-45^{\circ} \mathrm{C}$ temperature by $5 \mathrm{~mL}$ which already contains $5 \mathrm{~mL}$ bacterial suspension equivalent of $0.5 \mathrm{McF}$ arland. While the negative control using only MHA media without bacterial suspension. Throughout the test and control media were incubated in an incubator at $37^{\circ} \mathrm{C}$ for $18-24 \mathrm{hrs}$

\section{Comparison of antibacterial activity values}

The determination of the appeal done by way of one sterile petri dish diameter of $15 \mathrm{~cm}$ was prepared and put $45 \mathrm{~mL}$ of the bacterial suspension equivalent to a $0.5 \mathrm{McF}$ arland on each cup, then added $45 \mathrm{~mL}$ order MHA temperature $40-450^{\circ} \mathrm{C}$. The mixture was homogenized and then allowed to stand until solidified. In each cup, made 6 holes using the perforator. On hole number 1, 2, 3 into which is inserted a $100 \mathrm{~mL}$ solution of ethanol extract of leaves, whereas the number 4, 5, 6 holes included $100 \mathrm{~mL}$ solution of ethanol extract of the leaves suji. Extract solution which included an extract concentrations provide inhibitory diameter approaching the diameter of the resulting inhibition of the ethanol extract solution of other test substances at certain concentrations. Tests conducted comparative value triplo. Positive control, sterile petri dish diameter of $5 \mathrm{~cm}$ was prepared and poured into it MHA $40-45^{\circ} \mathrm{C}$ temperature by $5 \mathrm{~mL}$ which already contained $5 \mathrm{~mL}$ bacterial suspension equivalent of 0.5 McFarland. While the negative control using only MHA media without bacterial suspension. Throughout the test and control media were incubated in an incubator at $37^{\circ} \mathrm{C}$ for $18-24 \mathrm{hrs}$. Data diameter growth inhibition was observed and detected using a caliper. Then be made curve relationship between inhibition diameter ( $\mathrm{mm}$ ) on the Y-axis against log concentration (ppm) on the X-axis. Furthermore, the linear regression line drawn searched the mathematical equations of the straight line.

\section{Determination of minimum inhibitory concentration (MIC) grow} and minimum kill concentration (MBC)

Determination of MIC grow conducted by preparing microplate and entirely filled with $100 \mathrm{~mL}$ of media MHB. Well first as a negative control containing only media MHB. In the second well containing MHB media and added $10 \mathrm{~mL}$ of the bacterial suspension equivalent to a 0.5 McFarland. Well, another containing MHB media and extract test. Extracts inserted into eppendorf tube and dissolved in DMSO to obtain the concentration of the extract solution stock. Then extract as much as $100 \mathrm{~mL}$ stock solution was taken and placed on a microplate well. Further dilution stratified to obtain the appropriate concentration range activity test results. Well into the whole test, inoculated $10 \mathrm{~mL}$ test bacteria. Microplate was incubated in an incubator at $37^{\circ} \mathrm{C}$ for 18 24 hrs. Growing measurement results (MIC be well with the smallest concentration which did not give a cloudiness in the test medium after an incubation period. Then from the well, was the determination of minimum kill concentration (MBC) by scraping the results of incubation 
of the test medium on the surface of the solid MHA media. Positive and negative controls were also made as controls against sterility test medium and the media used. The test and control media were incubated in an incubator at $37^{\circ} \mathrm{C}$ for $18-24$ hrs [12].

\section{Potassium levels in extract}

Quantitative measurement of potassium concentration was conducted to determine the content of potassium contained in the extract. Preparation of extracts made with dried destruction method and test extracts were analyzed using atomic absorption spectrophotometry (AAS).

\section{RESULTS AND DISCUSSION}

\section{Extraction and determination of parameter extract}

The extraction process is done by maceration method. $70 \%$ ethanol solvent selected for botanicals used are leaves and leaf suji is dried so that the required ethanol simplisia with large water content for the process of wetting. The water content was instrumental in the process of opening the dried simplisia pores so that the solvent would be able to $\log$ in and easily contact, ] dissolving and drawing secondary metabolites contained therein [13]. A viscous and thick extracts were obtained after rotary evaporated. This extract was then analyzed for its extract parameters including organoleptic, yield, and moisture content [14].

Organoleptic ethanol extract of bay leaves was blackish brown, typical aromatic extracts and thick texture. While the ethanol extract of the suji leaves the resulting green-brown, aromatic extracts and texture typical lumpy. The yield of bay and suji leaves were 13.23 and $8.04 \% \mathrm{w} / \mathrm{w}$, respectively. The water content of bay and suji leaves were 8 and $5 \%$, respectively, which met the specified conditions. The water content in the extract should not be more than $10 \%$ to avoid the rapid growth of the fungus in the extract [15].

\section{Phytochemical screening results}

Results of phytochemical screening botanicals and extracts from bay and suji leaves are shown in Table 1.

Our phytochemical screening results were consistent with the literature that says that the bay leaves contained secondary metabolites of tannins and flavonoids $[16,17]$ while suji leaves contain secondary metabolites were flavonoids, and polyphenols [18]. However, both the samples and ethanol extracts bay leaf and ethanol extracts of suji leaves, not contained alkaloids, saponins, and quinones.

\section{TLC results}

The result of the determination of the profile TLC of ethanol extract of bay and suji leaves can be seen in Table 2 .

From the results of the TLC profile, it might be concluded that there were at least five and six non-polar compounds in ethanol extract of bay and suji leaves, respectively.

\section{Table 1: Phytochemical screening of bay and suji leaves}

\begin{tabular}{|c|c|c|c|c|}
\hline \multirow{2}{*}{$\begin{array}{l}\text { Secondary } \\
\text { metabolites }\end{array}$} & \multicolumn{2}{|l|}{ Bay leaves } & \multicolumn{2}{|l|}{ Suji leaves } \\
\hline & Simplisia & Extract & Simplisia & Extract \\
\hline Alkaloids & - & - & - & - \\
\hline Flavonoids & + & + & + & + \\
\hline Tannins & + & + & + & + \\
\hline Saponin & - & - & - & - \\
\hline Triterpenoids & - & - & + & + \\
\hline Steroids & + & + & & \\
\hline Polypheenols & + & + & + & + \\
\hline Quinone & - & - & - & - \\
\hline $\begin{array}{l}\text { Monoterpenoid \& } \\
\text { sesquiterpenoids }\end{array}$ & + & + & + & + \\
\hline
\end{tabular}

+: Detected, -: Not detected
Test results of confirm bacteria

Early identification of $S$. dysenteriae ATCC 13313 was to grow them in media selectively-media Salmonella-Shigella agar. It was confirmed that $S$. dysenteriae could grow on selective media with colony morphology include color translucent colonies without black core and a spherical convex. This was consistent with $S$. dysenteriae colony morphology found in the literature [19]. Observations can be seen in Fig. 1.

Further identification by Gram-staining - When viewed under a microscope, Gram-positive bacteria in purple due to Gram-positive bacterial cell wall consists of peptidoglycan thick and will shrink by bleaching treatment/alcohol causes the pores shrink, so will retain the primary dye complex (CGV-Lugol). Gram-negative bacteria, on the other hand, have the structure of cell walls thinner and thicker lipid structures. Lipids in Gram-negative would be dissolved by the bleaching solution (alcohol), thus increasing the power seeped so under the microscope will be blue because the dye primer (CGV-Lugol) lost due to alcohol flushing and stained by the dye is methylene blue counter [20]. It was observed the test bacteria were Gram-negative because it showed the form of rods and blue corresponding to literature as shown in Fig. 2.

Furthermore, biochemical test conducted on the basis of metabolism caused by enzyme working power [19]. The results of biochemical tests can be seen in Table 3 .

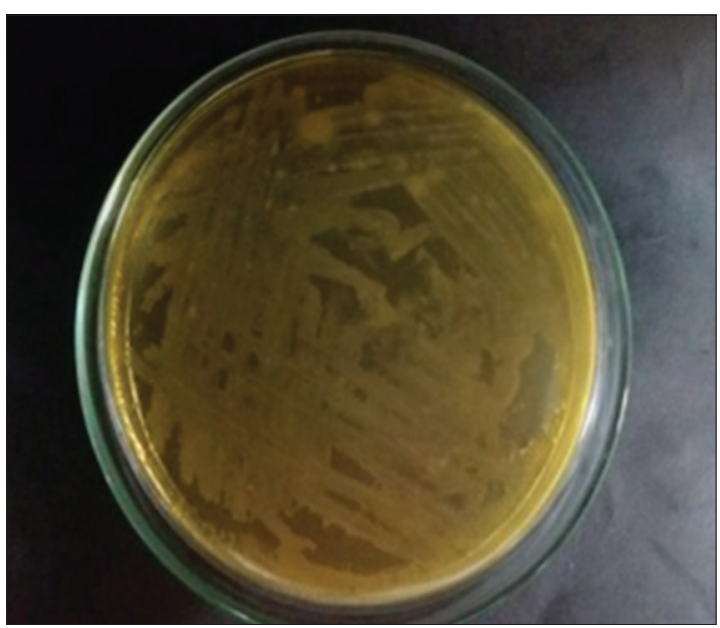

Fig. 1. Shigella dysenteriae colonies on an agar medium Shigella-Salmonella

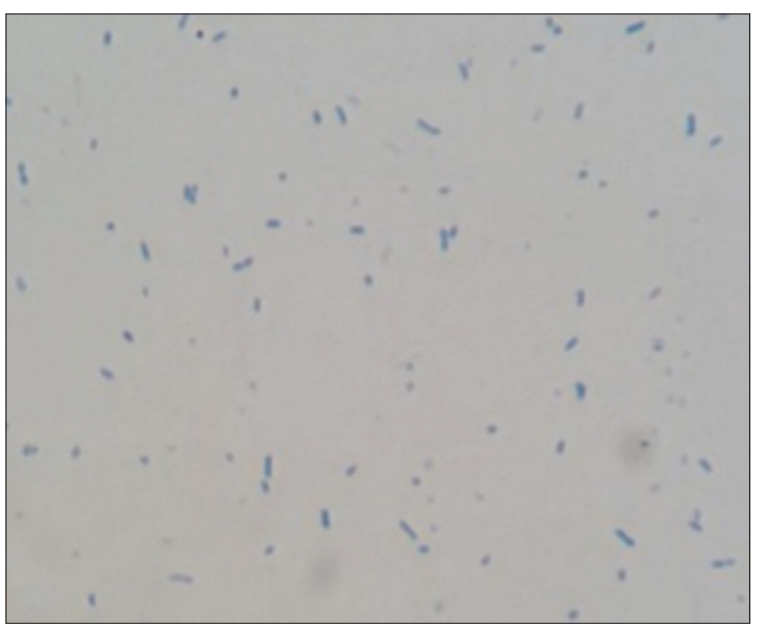

Fig. 2: The results of Gram-stain Shigella dysenteriae 
Table 2: TLC of bay and suji leaves ethanol extracts

\begin{tabular}{|c|c|c|c|c|c|c|c|c|}
\hline \multirow[t]{3}{*}{ Spots } & \multirow{2}{*}{\multicolumn{2}{|c|}{ Rf }} & \multirow{2}{*}{\multicolumn{2}{|c|}{ Visible light }} & \multicolumn{4}{|l|}{ Sinar UV } \\
\hline & & & & & \multicolumn{2}{|l|}{254} & \multicolumn{2}{|l|}{366} \\
\hline & Bay leaves & Suji leaves & Bay leaves & Suji leaves & Bay leaves & Suji leaves & Bay leaves & Suji leaves \\
\hline 1 & 0.975 & 0.975 & Dark green & Dark green & Dark green & Dark green & Dark pink & Pink \\
\hline 2 & 0.938 & - & Yellow & - & Light green & - & Dark pink & - \\
\hline 3 & 0.875 & 0.875 & Dark green & Dark green & Yellow & Dark green & Dark blue & Pink \\
\hline 4 & - & 0.813 & - & Light yellow & - & Purple & - & - \\
\hline 6 & - & 0.463 & - & Light yellow & - & - & - & Dark blue \\
\hline 7 & - & 0.35 & - & Light yellow & - & - & - & Dark blue \\
\hline 8 & 0.325 & - & Brown & - & - & - & Dark blue & - \\
\hline 9 & - & 0.225 & - & Light yellow & - & - & - & Dark blue \\
\hline
\end{tabular}

-: No spots, TLC: Thin layer chromatography, UV: Ultraviolet

\section{Results of testing activities}

Testing the antibacterial activity of ethanol extract of bay and suji leaves performed using agar diffusion method using a perforation technique, results of which shown in Fig. 3.

Based on this work, the ethanol extract of suji leaves began antibacterial activity at a concentration of at least $40 \% \mathrm{w} / \mathrm{v}$. While the ethanol extract of bay leaves began to show antibacterial activity at a concentration of at least $10 \% \mathrm{w} / \mathrm{v}$ greater the concentration of the extract, the inhibition produced diameter increases. This was because, the ethanol extract of suji and bay leaves have diffusion into media so good, so the secondary metabolites contained therein were able to produce antibacterial activity against $S$. dysenteriae.

\section{Results determination of comparative activities}

The determination of the antibacterial comparative activity of ethanol extract of bay leaves of the ethanol extract of the suji leaves conducted to determine the best extracts activity at certain concentrations. The determination was carried out by the agar diffusion method. The results of the determination of the comparative activities can be seen in Table 4.

Based on the data in Table 4, then graphed the relationship between log concentration of the extract with a diameter of inhibition. It was found that the linear regression equation for the ethanol extract of bay leaves was $y=10,217 x-68.55$ and for the ethanol extract of suji leaves was $y=7,6577 x-49.77$. As shown, the Table 5 indicated that at a concentration of $20 \% \mathrm{w} / \mathrm{v}$, bay leaves ethanol extract provided inhibitory diameter $16.47 \mathrm{~mm}$. Diameter value was then substituted in the equation $y=7,6577 x-49.77$ to obtain the value of $x$ is 8.698 and antilog value that is $49.969 \times 108 \mathrm{ppm}$, or about $49.96 \% \mathrm{w} / \mathrm{v}$. The meaning of these antilog values indicate that the concentration of ethanol extract of suji leaves which can provided inhibitory diameter of $16.47 \mathrm{~mm}$ was equal to $49.96 \% \mathrm{w} / \mathrm{v}$. The comparative value was obtained by comparing the concentration of ethanol extract of suji leaves with the concentration of ethanol extract of bay leaves. Suji leaf ethanol extract concentration of $49.96 \% \mathrm{w} / \mathrm{v}$ compared with the concentration of ethanol extract of leaves of $20 \% \mathrm{w} / \mathrm{v}$ to obtain the comparative value of the ethanol extract of the leaves suji with bay leaves ethanol extract against $S$. dysenteriae of 1:0.4. This meant that to produce the same inhibitory diameter to 1 part of ethanol extract of leaves suji comparable to 0.4 parts of the ethanol extract of bay leaves.

Determination of MIC growing and minimum kill concentration extract (MBC)

Testing grows MIC, and minimum kill concentration (MBC) were performed by microdilution method which was the method of turbidimetry with the view turbidity indicates growth of test bacteria (S. dysenteriae). The advantage of this method is the material needed microdilution less than using macrodillution. MIC was determined by observing the killing power of the smallest concentration of the extract was used to kill test bacteria. Killing ability was shown by
Table 3: Biochemical test results of Shigella dysenteria ATCC 13313

\begin{tabular}{lll}
\hline Biochemical test & $\begin{array}{l}\text { Shigella } \\
\text { dysenteriae ATCC } \\
\mathbf{1 3 3 1 3}\end{array}$ & $\begin{array}{l}\text { Shigella } \\
\text { dysenteriae (Kelly } \\
\text { et al. 1995) }\end{array}$ \\
\hline Motility & - & - \\
Glucose & + & + \\
Lactose & - & - \\
Mannose & - & - \\
Malatose & - & - \\
Saccharose & - & - \\
Indol & - & - \\
TSIA & $-/ \mathrm{H}_{2} \mathrm{~S}-$ & $-/ \mathrm{H}_{2} \mathrm{~S}-$ \\
Urea & - & - \\
Metil red (MR) & + & + \\
Voges-Proskauer (VP) & - & - \\
Simon citrate & - & - \\
\hline +: React,-: Not react & &
\end{tabular}

Table 4: Results of determination of comparative value bay and suji ethanol extracts against Shigella dysenteriae ATCC 13313

\begin{tabular}{|c|c|c|c|}
\hline $\begin{array}{l}\text { Concentration } \\
\text { of bay leaves } \\
\text { ethanol } \\
\text { extract }(\% \mathrm{w} / \mathrm{v})\end{array}$ & $\begin{array}{l}\text { Inhibition } \\
\text { zone (mm) }\end{array}$ & $\begin{array}{l}\text { Concentration } \\
\text { of suji leaves } \\
\text { ethanol } \\
\text { extract }(\% \mathrm{w} / \mathrm{v})\end{array}$ & $\begin{array}{l}\text { Inhibition } \\
\text { zone (mm) }\end{array}$ \\
\hline \multirow{4}{*}{20} & 16.5 & 40 & 16.4 \\
\hline & 16.1 & & 16.2 \\
\hline & 16.8 & & 16.2 \\
\hline & 16.47 & & 16.27 \\
\hline \multirow[t]{4}{*}{40} & 19.1 & 80 & 17.7 \\
\hline & 18.8 & & 17.8 \\
\hline & 18.7 & & 17.4 \\
\hline & 18.87 & & 17.65 \\
\hline \multirow[t]{4}{*}{80} & 22.8 & 100 & 19.4 \\
\hline & 22.5 & & 20.1 \\
\hline & 22.5 & & 19.7 \\
\hline & 22.6 & & 19.7 \\
\hline
\end{tabular}

the test medium that becomes clear in accordance with its negative. Clear controls stated that the bacteria had undergone lysis. However, turbidity difficult to observe because of the influence that disrupt observation. For this, it should be made a negative control containing media and extract to compare the turbidity of the extract or the growth of test bacteria. In addition, observations of the growth of test bacteria would clearly observe through the subculture of the results on the media to MHA sterile microplate with scratch plate method, which can simultaneously determine the value of the minimum kill concentration (MBC). MIC of both extracts could not be determined because of sediment and color of the extract that prevents bacterial 
Table 5: MIC and MBC of ethanol extact of bay and suji leaves

\begin{tabular}{|c|c|c|c|c|c|}
\hline \multicolumn{3}{|l|}{ MIC } & \multicolumn{3}{|c|}{ MBC (Minimum kill concentration) } \\
\hline \multirow{3}{*}{$\begin{array}{l}\text { Extract } \\
\text { concentration }(\% \mathrm{~b} / \mathrm{v})\end{array}$} & \multicolumn{2}{|c|}{ Colony growth } & \multirow{3}{*}{$\begin{array}{l}\text { Extract } \\
\text { concentration }(\% b / v)\end{array}$} & \multicolumn{2}{|c|}{ Colony growth } \\
\hline & \multicolumn{2}{|c|}{ Shigella dysenteriae } & & \multicolumn{2}{|c|}{ Shigella dysenteriae } \\
\hline & Bay leaves & Suji leaves & & Bay leaves & Suji leaves \\
\hline 0.625 & + & + & 40.00 & - & - \\
\hline 1.25 & + & + & 20.00 & - & - \\
\hline 2.5 & + & + & 10.0 & + & + \\
\hline 5.00 & + & + & 5.00 & + & + \\
\hline 10.00 & + & + & & & \\
\hline 20.00 & - & - & & & \\
\hline 40.00 & - & - & & & \\
\hline
\end{tabular}

MIC: Minimum inhibitory concentration

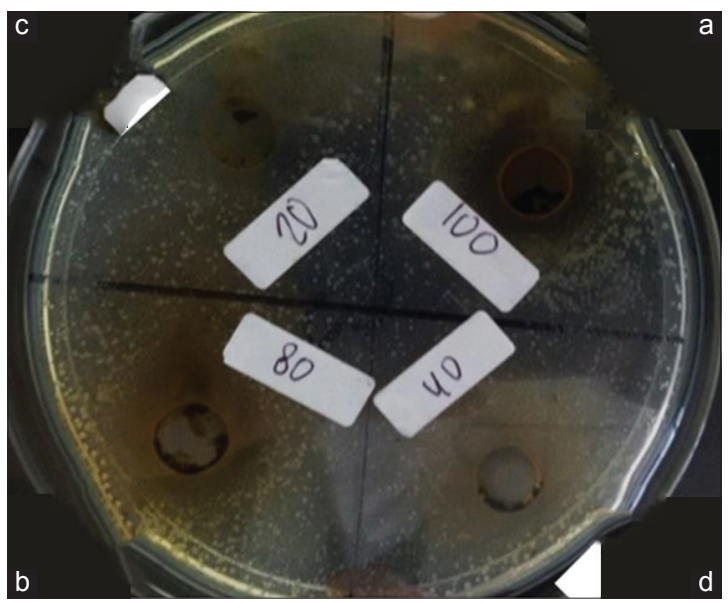

Fig. 3: The diameter of the inhibition of ethanol extract of suji leavesi; (a) The ethanol extract of suji leaves concentration of $100 \% \mathrm{w} / \mathrm{v}$, (b) the ethanol extract of leaves suji concentration of $80 \% \mathrm{w} / \mathrm{v}$, (c) The ethanol extract of suji leaves concentration of $40 \% \mathrm{w} / \mathrm{v}$, (d) the ethanol extract of leaves suji concentration of $20 \% \mathrm{w} / \mathrm{v}$

growth observations. To observe more clearly the growth of bacteria, then performed etching every media test on MHA microplate into the growth media, which also determined the value of the minimum kill concentration (MBC) (Table 5). Based on these data, it can be concluded that the ethanol extract of bay and suji leaves has a MIC value in the concentration range of $10-20 \% \mathrm{w} / \mathrm{v}$.

\section{Potassium quantitative test results}

Potassium content analysis made to extract thick using AAS. Sample preparation was performed by dry destruction. Condensed extract samples were used as much as $5 \mathrm{~g}$ dry then carried destruction and made the $25 \mathrm{~mL}$ sample solution. The standard solution that had been made with concentrations of 100, 200, 300, and 400 ppm were measured to obtain the linear regression equation $y=0,00117 \mathrm{x}$, and the correlation coefficient was 0.996910 . We obtained results of $2054 \mathrm{ppm}$ $(1.027 \% \mathrm{w} / \mathrm{w} /)$ and $7590 \mathrm{ppm}(3.795 \% \mathrm{w} / \mathrm{w})$ for the ethanol extract of bay and suji leaves, respectively. Based on the literature, potassium levels are required to provide potassium intake in patients with hypokalemia dysentery is $30 \mathrm{mEq}$ equivalent to $1.17 \mathrm{~g} / \mathrm{L}$ or $1170 \mathrm{ppm}$ [6]

\section{CONCLUSION}

It can be concluded that the ethanol extract of bay and suji leaves has antibacterial activity against bacteria $S$. dysenteriae ATCC 13313. Rated comparative activity of the ethanol extract of the suji leaves with bay leaves ethanol extract was 1:0.4 which means to generating resistor diameter equal to 1 part suji leaf ethanol extract equivalent to 0.4 parts of the ethanol extract of bay leaves. The minimum kill concentration ethanol extract of bay and suji leaves ethanol extract was in the range of $10-20 \% \mathrm{w} / \mathrm{v}$. Both bay and suji leaves have potential as a supplier of potassium in patients with hypokalemia dysentery.

\section{ACKNOWLEDGMENT}

We thank Putu Listynelia Wirda Andanseswari for technical assistance.

\section{REFERENCES}

1. Media Litbang Kesehatan Indonesia. Disentri, 2004. Available from: http://www.209.85.175.104. [Last accessed on 2015 Sep 10].

2. Tjay T, Rahardja K. Obat-obat Penting Khasiat, Penggunaan, dan Efek Sampingnya. Edisi VI. Jakarta: PT Elex Media Komputindo Kelompok Gramedia; 2007. p. 124.

3. WHO (World Health Organization). Diarrhoeal Disease, 2009. Available from: http://www.who.int.vaccineresearch/disease/diarrhoeal/en/ index6.html. [Last accessed on 2015 Sep 10].

4. Yayasan Stroke Indonesia. Disentri Pada Bayi Usia 2 Minggu, 2012. Available from: http://www.yastroki.or.id/read.php?id=392. [Last accessed on 2015 Sep 11].

5. Larry J. Potassium. Merck Manual Home Health Handbook. USA: Merck; 2008.

6. Jawetz E, Melnick JL, Adelberg EA. Jawetz, Melnick, \& Adelberg's Medical Microbiology. New York: McGraw Hill Medical; 2010.

7. Health Technology Assesment Indonesia. Penggunaan Siprofloksasin di Indonesia. Indonesia: HTA; 2005. p. 28.

8. Wijaya H. Uji Efektivitas Antibakteri Ekstrak Etanol Daun Salam (Sizygium polyanthum) Terhadap Shigella dysenteriae Isolat Labkesda Surabaya Secara In Vitro, 2009. Available from: http://www.old.fk.ub. ac.id/artikel/id/filedownload/kedokteran/Hendra\%20darmawan $\% 20$ 0710713047pdf. [Last accessed on 2015 Sep 11].

9. Andarini D. Thesis, Fakultas Farmasi. Jakarta: Univeristas Pancasila; 2012.

10. Harborne JB. Metode Fitokimia. $2^{\text {nd }}$ ed. Translated by Kosasih, Penerbit. Bandung: ITB; 1987

11. Farnsworth NR. Biological and phytochemical screening of plants. J Pharm Sci 1966;55(3):225-76.

12. Duncan F. MCB 1000L Applied Microbiology Laboratory Manual. $4^{\text {th }}$ ed. New York: McGraww-Hill Companies; 2005.

13. Hargono D. Sediaan Galenik. Jakarta: Departemen Kesehatan Republik Indonesia; 1986 , p. 88.

14. Departement Kesehatan RI. Parameter Standar Umum Ekstrak Tumbuhan Obat. Jakarta: Direktorat Jendral Pengawasan Obat dan Makanan dan Direktorat Pengawasan Obat Tradisional; 2000. p. 76-80.

15. Soetarno S, Soediro IS. Standarisasi Mutu Simplisia dan Ekstrak Bahan Obat Tradisional. Farmasi: Presidium Temu Ilmiah Nasional Bidang; 1997.

16. Dalimartha S. Atlas Tumbuhan Obat Indonesia. Jilid 2. Jakarta: Trubus Agriwidya; 2007. p. 71-7, 162-4.

17. Thomas AN. Tanaman Obat Tradisional. Jilid 2. Yogyakarta: Kanisius; 2007. p. 104-6.

18. Hutapea JR. Inventaris Tanaman Obat Indonesia. Jilid III. Jakarta: Departemen Kesehatan Republik Indonesia; 1994.

19. Kelly FC. Microbiology. New York: Appleton-Century-Crofts Inc.; 1995.

20. Brown A. Microbiological Application Lab Manual. $8^{\text {th }}$ ed. New York: McGraw-Hill Companies; 2001. p. 45. 